\title{
Modulation: A Translation Method to Obtain Naturalness in Target Language Texts
}

\author{
Adventina Putranti \\ putranti@usd.ac.id \\ Department of English Letters, Universitas Sanata Dharma
}

\begin{abstract}
One of the requirements in order to produce equivalent translation is that the translation must sound natural for target language (TL) readers both lexically and grammatically. This naturalness can be obtained through the use of both lexical items and grammar familiar to the TL readers. However, naturalness in translation is not always easy to achieve. One of the causes is the difference in the way the source language (SL) and TL readers express a certain message in their languages. According to Vinay and Darbelnet (1995) this difference can be overcome by applying a translation method called modulation. Modulation is a method in which translators try to maintain naturalness by using various form the message done by changing the point of view. This procedure is usually chosen when translators find that literal translation would result in awkward or unnatural translation.
\end{abstract}

Keywords: modulation, naturalness, equivalence

\section{Introduction}

It has been understood by translators that translating a text is not just a matter of finding the correct words in the TL, and using the correct TL grammar. An accurate translation may still sound awkward when the translation is done literally. What is meant by 'awkward' is that the translation does not sound natural in the language of the target readers. When it happens, different point of view between the SL and TL readers may be one of the causes.

In English - Indonesian translation and vice versa, the issue of naturalness has also become a complication in the process of translation due to the wide lexical gap that is rooted from cultural differences. To overcome such a problem, a translation method is needed, and this paper intends to discuss a suitable translation method to solve the problem of naturalness as the result of different point of view between SL and TL readers.

\section{Translation, Equivalence, and Naturalness}

Nida and Taber define translation as "reproducing in the receptor language the closest natural equivalent of the source language message, first in terms of meaning and secondly in terms of style" (Nida \& Taber, 1974: 12). By this definition, the term 'equivalent' is more focused on meaning rather than style. It can also be said that translators cannot just pay attention to the accuracy in translating grammatical elements in the texts or in searching for accurate substitutes for the SL words. Translators' priority is to consider whether the translation would be read and understood by the TL readers as it is intended by the writer of the SL text (Nida and Taber, 1974: 8).

Nida and Taber also mention that "the best translation does not sound like a translation" (Nida \& Taber, 1974: 12). Further, they also state that the readers of the TL text must give a response to the text in a 
substantially the same manner as the readers of the SL text (Nida \& Taber, 1974: 24). Responding a translation in a substantially the same manner as the SL readers implies that the translators must be able to find a "one-to-one equivalent" (Newmark, 1988: 114) of a SL item in the TL. However, not only does the concept of 'one-to-one' implies complications in the scope of finding one-to-one substitute of the SL item in the TL, especially when the gap between the SL and the TL is wide, but it also demands the translators' effort to present a natural TL. These two requirements indicate that naturalness in translation is one requirement in order to produce equivalent message in the TL. Thus, it can be concluded that translation is concerned with not only transferring message written in one language into another language accurately, but also obtaining the naturalness of message delivery, so that equivalent translation can be produced.

Naturalness in translation can be seen in the use of appropriate TL expressions as well as TL structure. According to Nida, the word 'natural' in translation covers three areas, "(1) the receptor language and culture as a whole, (2) the context of the particular message, and (3) the receptor language audience" (Nida in Venuti ed., 2000: 136). This means that natural translation can be obtained when the translators also pay attention to the cultural background of the TL readers, the context of the text being translated, as well as the characteristics of the TL readers. Considering the coverage, not all translation, then, can be handled literally. By this, it means that, even when correct TL sentence structure and vocabulary are expected to express the SL message in the TL, TL readers would not respond the message in a substantially the same manner as SL readers.

A problem commonly occurring is the failure of the translation to transfer SL message due to cultural and mindset differences between the SL readers and the TL readers. These differences are usually reflected in the variety of lexical items and grammar used in one language compared to another. If this happens, the situation may lead to the fact that TL readers will be unable to understand the message delivered in the translation because the translation does not sound natural for the TL readers.

When such a problem of naturalness occurs in translating process, an appropriate translation method is required to overcome the problem. According to Newmark, translation methods refer to how an SL text is translated into a TL (Newmark, 1988, p. 81). In applying a method, translators must follow certain procedures to handle smaller units in a text such as words, phrases, and sentences in order to obtain equivalent translation, in which naturalness is part of the requirements.

\section{Modulation}

As mentioned earlier, not all texts can be translated literally. When a SL text is literally translated into another language, in which there is a wide lexical gap, there would be a lot of missing information in TL. This issue is identified by Bassnett as 'untranslatability'. According to Bassnett, "untranslatability occurs when there is no lexical or syntactical substitute in the TL for an SL item" (1991: 32). Bassnett's concept about untranslatability is relevant with the issues of lexical gap proposed by Vinay and Darbelnet, particularly when the untranslatability is related to the absence of lexical substitute in the TL. To overcome this problem, Vinay and Darbelnet propose one possible translation method called modulation.

Modulation, according to Vinay and Darbelnet, is defined as "a variation through a change of viewpoint, of perspective, and very often of category of thought" (Newmark, 1988: 88). By this definition, Vinay and Darbelnet want to convey that, in many cases, TL readers' different perspectives, viewpoint, and mindset are the causes of the failure of a translated text to deliver the SL message. One indication of the failure is when the translation has been done correctly, but the result is "considered unsuitable, unidiomatic or awkward in the TL" (Venuti ed., 2000: 89).

Further, Vinay and Darbelnet state that there are two kinds of modulation. The first is called fixed or obligatory modulation, while the second is free modulation (Vinay \& Darbelnet in Venuti ed., 2000: 89) or optional 
modulation according to Munday (2008: 57). Fixed modulation is applied when a preferred expression in the TL is more favorable to use rather than literal translation of the expressions. Whether or not an expression is more favorable and more idiomatic in the TL is confirmed by a dictionary (Vinay \& Darbelnet in Venuti ed., 2000: 89). Meanwhile, free modulation can be said as the translators' unique solutions to reach the highest degree of equivalence in their translation (Vinay \& Darbelnet in Venuti ed., 2000: 89).

Munday, quoting Vinay and Darbelnet, states that modulation usually occurs at the level of message. Meanwhile, changes at grammatical level are recognized as transposition (Munday, 2008: 58). At the level of message, modulation is still divided into several categories: concrete for abstract, cause - effect, part - another part, reversal of terms, negation of opposite, active to passive (and vice versa), space for time, rethinking of intervals and limits (in space and time), and change of symbol (including fixed and new metaphor).

\section{Instances of Modulation in English - Indonesian Translation and vice versa}

In English - Indonesian translation and vice versa, modulation is a translation method that can be useful to overcome problems of message transfer considering that there are a lot of cultural differences between the two. The first example in which modulation is required to make the translation sound natural can be found in the translation of the responses for an expression of gratitude 'thank you'. Some possible responses for this expression are 'you are welcome', 'never mind', 'any time', and 'don't mention it'. When these responses are translated into Indonesian literally, the result will be 'Anda diterima' (you are welcome), 'jangan dipikirkan' (never mind), 'kapan saja' (any time), or 'jangan sebutkan itu' (don't mention it). None of the translation mentioned here is natural. In order to produce more natural translation, responses for a thanking expression in Indonesian, such as 'terima kasih kembali' (thank you back to you), and 'samasama' (thank you just the same) are more common, thus more natural.
Another example is the translation of an active sentence, which, in Indonesian, is translated into passive. Sentences such as 'I left my book at home' and 'I cut my finger' will not convey substantially the same meaning when it is translated literally into 'saya meninggalkan buku saya di rumah' and 'saya memotong jari saya'. In the SL sentences, the thematic role of the subject ' $\mathrm{I}$ ' is an experiencer (Fromkin, Rodman, \& Hyams, 2003: 193). An experiencer is someone who perceives or experiences something. In 'I left my book at home', the subject experienced leaving his/her book at home, In 'I cut my finger', the subject experienced being hurt because his/her finger was accidentally injured. When this two sentences are translated into an active voice, the verbs 'meninggalkan' and 'memotong' imply the sense of deliberate actions. The subject is not anymore an experiencer, but an agent, that is someone who performs an action (Fromkin, Rodman, \& Hyams, 2003: 192). To solve such a problem, changing the SL active voice into a TL passive voice, particularly stative passive, would make the translation more natural. TL sentences like 'buku saya tertinggal di rumah' (my book was left at home) and 'jari saya tersayat' (my finger was accidentally cut) are more natural in the TL.

The next example that is also interesting to discuss is the translation of a question 'what's your address?'. The question word 'what' is used to ask for specific information about something (Longman Dictionary of Contemporary English, 2004: 1877). This sentence is, then, commonly translated into 'dimana alamatmu?' (where is your address?). The back translation written in brackets indicates the TL readers perceive the question as asking for location. Although the Indonesian translation does not literally translate the SL sentence, this translation is natural for the TL readers because of the different perspective.

The following example may show how free modulation is applied. In the sentence 'Dengan meminum hanya satu sendok makan minyak zaitun setiap hari, resiko terkena kanker dapat berkurang hingga tinggal 25\% saja', a translator would probably translate it into 'By taking only a tablespoonful of olive oil a day, the risk of the occurrence of cancer can be reduced up to $75 \%$ '. The modulation can be 
seen from the change of perspective about the percentage as the result of the use of verb 'reduce'.

The last example is a metaphoric expression 'the apple of my eye', meaning 'to be loved very much by me' (Longman Dictionary of Contemporary English, 2004: 60). The common Indonesian translation for this expression is 'jantung hatiku'. 'Jantung' and 'hati' both mean 'heart'. As mentioned earlier, modulation also covers the discussion of a change of symbol. From the back translation, it can be seen that the two languages use different expressions to symbolize someone important, that is 'apple' and 'eye' in English, and 'heart' in Indonesian.

\section{Conclusion}

From the discussion above, some conclusions can be drawn. First, literal translation does not always transfer SL message into the TL because literal translation may result in unnatural or awkward translation. Second, when literal translation fails to transfer SL message into the TL, untranslatability may occur. Untranslatability is usually rooted from the absence of lexical or syntactical substitutes in the TL. The absence of the substitutes may also be caused by different viewpoint, perspective, or category of thought between SL and TL readers. Finally, modulation is a translation method that can be applied to the problem, so that the TL text could be more natural. When a SL text cannot be translated into a TL unless modulation is applied, the modulation is obligatory. Meanwhile, when modulation works as a translator's technique to obtain the closest equivalent, it is called free modulation.

\section{References}

Bassnett, Susan. Translation Studies Revised Edition. London: Routledge, 1991.

Fromkin, Victoria, Robert Rodman, \& Nina Hyams. An Introduction to Language. Seventh Edition. Boston: Wadsworth, 2003.

Longman Dictionary of Contemporary English. The Living Dictionary. Harlow: Pearson Education Limited, 2004.

Munday, Jeremy. Introducing Translation Studies: Theories and Applications. Second Edition, London: Routledge, 2008.

Newmark, Peter. A Textbook of Translation, New York: Prentice Hall International.

Nida, Eugene A. \& Charles Taber. The Theory and Practice of Translation. Leiden: E.J. Brill, 1974.

Nida, Eugene. Principles of Correspondence. In Lawrence Venuti (Ed.) Translation Studies Reader (pp. 126 - 140). New York: Routledge, 2000.

Vinay, Jean-Paul \& Jean Darbelnet. A Methodology for Translation. Translated by Juan C. Sager and M.J. Hamel. In Lawrence Venuti (Ed.).The Translation Studies Reader (pp. 84 - 93). New York: Routledge, 2000, 